\title{
PLANKTON STRUCTURE A IN SHALLOW COASTAL ZONE AT ADMIRALTY BAY, KING GEORGE ISLAND, WEST ANTARCTIC PENINSULA (WAP): PICO, NANO AND MICROPLANKTON AND CHLOROPHYLL BIOMASS
}

http://dx.doi.org/10.4322/apa.2014.033

\author{
Denise Rivera Tenenbaum ${ }^{1, *}$, José Juan Barrera-Alba ${ }^{1, * *}$, \\ Renatha Barboza Duarte', Márcio Murilo Barboza Tenório ${ }^{1, * \star *}$
}

'Laboratório de Fitoplâncton Marinho, Instituto de Biologia, Universidade Federal do Rio de Janeiro - UFRJ, Rio de Janeiro, RJ, Brazil e-mail: *deniser@biologia.ufr..br; **juanalba@biologia.ufr.br; ***marcio.tenorio@biologia.ufrj.br

\begin{abstract}
The phytoplankton composition and biomass are being monitored in Admiralty Bay, Antarctic Peninsula since 2002 to detect possible interannual changes on a long-term perspective. In this report, we present the preliminary results of the 2009/2010 monitoring program regarding phytoplankton size-structure and biomass. Even if mean microplankton densities were similar between December 2009 and February 2010, diferent phytoplankton groups dominated each sampling period. Pennate diatoms showed highest contribution in December, whereas athecate dinoflagellates were the most abundant microplanktonic group in February. Pico and nanoplankton were only detailed during the second sampling period, and results showed that phytoplankton were dominated by cells $<10 \mu \mathrm{m}\left(\sim 10^{4}\right.$ and $10^{7}$ cells. $L^{-1}$, respectively). The shift in phytoplankton structure pointed out by the dominance of pico- and nano-size cells in phytoplankton and heterotrophic dinoflagellates in late summer must be confirmed by continuing the long-term monitoring program and the implementation of microvariation sampling effort to identify the factors that are actually influencing phytoplankton populations in this environment.
\end{abstract}

Keywords: microbial community, size-fraction structure, Antarctic coastal zone, PROANTAR

\section{Introduction}

The West Antarctic Peninsula (WAP) waters undergo extreme seasonal fluctuations in terms of light regime, sea-ice concentration and productivity (Delille, 2004). The WAP has experienced a significant rise in air temperature during the last 50 years $\left( \pm 0.56^{\circ} \mathrm{C}\right.$ per decade) (Marshall et al., 2002). Monitoring of biodiversity in shallow waters (30 m) at Admiralty Bay was implemented in 2002 by PROANTAR (Brazilian Antarctic Program) during the PROANTAR Operation XX (OPERANTAR) aiming to study the effects of environmental factors (natural and anthropogenic) on the microplanktonic community structure, through analysis of long-term temporal series. These activities were undertaken until 2010, through four surveys, including samplings in both early and late austral summer. Recent studies showed that in the Admiralty Bay, picoplankton and nanoplankton are the dominant groups, with microplankton diatoms as the second group in abundance. Between the decades of 1990 and 2000, several studies showed a decline in diatom contribution (Kopczynska, 2008), in relation to those observed in the continental shelf region. Based on these facts, since 2009 new approaches to phytoplankton monitoring have been established, including the analysis of size-fractioned pigments by spectrofluorometry, and the analysis of density and biovolume of pico- and nanoplankton 
by epifluorescence microscopy, and furthermore through a higher sampling frequency effort. Additionally, the composition of microphytobenthos species will be carried out to study the effects of environmental changes on this community in the nearshore Antarctic ecosystem.

In the present study we show preliminary results during the OPERANTAR XXVIII, between December 2009 and February 2010.

\section{Materials and methods}

\section{Study area}

Admiralty Bay $\left(62^{\circ} 03^{\prime}-12^{\prime} \mathrm{S}\right.$ and $\left.58^{\circ} 18^{\prime}-38^{\prime} \mathrm{W}\right)$, located at King George Island, is a deep fjord-like embayment with 500 $\mathrm{m}$ maximum depth at its centre (Rakusa-Suszczewski et al., 1993). The waters from the bay mix with the deep oceanic waters from Bellingshausen and Weddell Seas at its southern opening, which connects to the Bransfield Strait (RakusaSuszczewski, 1980; Lipski, 1987). The maximum depth varies between $60 \mathrm{~m}$ along the shores and $500 \mathrm{~m}$ in the centre of the bay. Deep currents generated by tides, frequent upwellings, vertical mixing of the entire water column and current velocities of $30-100 \mathrm{~cm} . \mathrm{s}^{-1}$ in the $0-100 \mathrm{~m}$ surface stratum are characteristic of the bay (Rakusa-Suszczewski, 1993). In the context of water column production, Admiralty Bay at nearshore can be considered as "high nutrient - low chlorophyll" (HNLC) Platt et al. (2003) showing high inorganic dissolved nitrogen (16.6-46.9 $\mu \mathrm{M})$ and phosphate (0.2-9.9 $\mu \mathrm{M})$ concentrations, while chlorophyll levels are lower than $1.7 \mu \mathrm{g} . \mathrm{L}^{-1}$ (Lange et al., 2007).

\section{Sampling}

The analysis of microplankton and chlorophyll was performed from aliquots of the $5 \mathrm{~L}$ water samples collected with a Van Dorn bottle from surface, middle water column and near the bottom $(\approx 30 \mathrm{~m})$ at five stations in December 2009 and in February 2010. The fractionation analysis of pico- and nanoplankton was performed only at three stations (AR, MP and CF) in February 2010, when three surveys were done. The Admiralty Bay location and the position of the sampling stations are shown in Figure 1.
At the same time, temperature and salinity measurements were carried out by the Laboratório de Química Orgânica Marinha (LabQOM), Instituto Oceanográfico da Universidade de São Paulo (The Marine Organic Chemistry Laboratory of the Oceanographic Institute of the University of São Paulo).

\section{Fixation and preparation of samples}

For microplankton ( $>20 \mu \mathrm{m}), 1 \mathrm{~L}$ aliquots were fixed with buffered formaldehyde ( $2 \%$ f.c.). In the laboratory, samples were analysed using the settling technique (Utermöhl, 1958) in an Olympus IX70 ${ }^{\circ}$ inverted microscope at 400x magnification.

For pico- $(<2 \mu \mathrm{m})$ and nanoplankton $(<20 \mu \mathrm{m})$, aliquots of $250 \mathrm{~mL}$ were stored in dark bottles and fixed with $0.22 \mu \mathrm{m}$ filtered glutaraldehyde ( $2 \%$ f.c.) at $4{ }^{\circ} \mathrm{C}$ until analysis. 5 and $30 \mathrm{~mL}$ were stained with DAPI (4',6-diamidino2 -phenylindole) at a final concentration of $0.01 \mu \mathrm{g} . \mathrm{L}^{-1}$ (Martinussen \& Thingstad, 1991), during 10 minutes and filtered respectively by $0.22 \mu \mathrm{m}$ (picoplankton) and $1.0 \mu \mathrm{m}$ (nanoplankton) polycarbonate black membrane filters (Poretics ${ }^{\circledR}$ ), and mounted on microscope slides between layers of immersion oil. Slides were stored at $-20^{\circ} \mathrm{C}$. Analyses were performed using an Olympus BX51 ${ }^{\circ}$ epifluorescence microscope with 1,000 x magnification. The number of heterotrophs was calculated based on the total counted using DAPI (UV filter combination) minus the number of autotrophs analysed by autofluorescence (Blue filter combination).

For chlorophyll biomass, $2 \mathrm{~L}$ aliquots were filtered through Whatman ${ }^{\star} \mathrm{GF} / \mathrm{F}$ filters for pigments analyses, while 0.8-2 L was used for the size structure study. In the latter case, water sampled at 3 depths was fractionated by serial filtration on $10 \mu \mathrm{m}$ and $2 \mu \mathrm{m}$ polycarbonate filters and GF/F. The filters were folded, placed into a $1.2 \mathrm{~mL}$ cryotube and immediately quick-frozen in liquid nitrogen $\left(-196^{\circ} \mathrm{C}\right)$ and stored at $-80^{\circ} \mathrm{C}$. Concentrations of chlorophyll $a$ and phaeophytin $a$ were assessed using a modified version of Neveux and Lantoine's (1993) method.

In order to normalize distributions and eliminate zero values, the biological data was transformed using $\log 10(x+1)$. Differences among surveys and sampling 


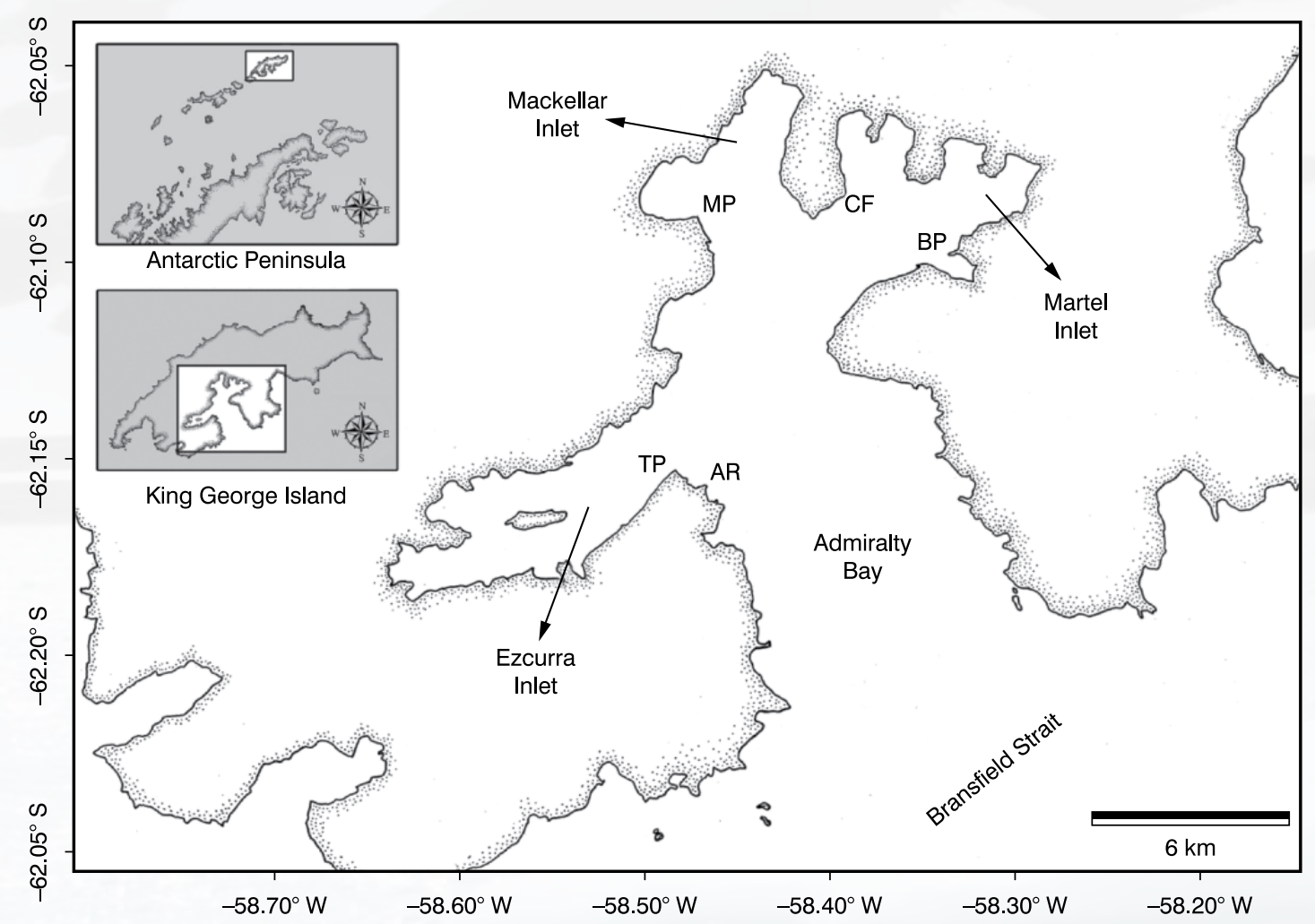

Figure 1. Study area (modified from Moura, 2009) with the position of the sampling sites: Ferraz Station (CF), Botany Point (BP), Machu Picchu (MP), Point Thomas (PT), Arctowski (AR)

stations were tested by a One-Way ANOVA with a KruskalWallis test $(p<0.05)$. Spearman's correlation factor was also calculated.

\section{Results}

\section{Microplankton and total chlorophyll biomass between early and late summer}

Although salinity showed little variation between sampling periods, values were on average lower in February $2010(33.9 \pm 0.2)$ than in December $2009(34.2 \pm 0.1)$. During the early summer, the water was relatively colder $\left(-0.13 \pm 0.11^{\circ} \mathrm{C}\right)$ than during late summer $\left(0.68 \pm 0.25^{\circ} \mathrm{C}\right)$. Although no great differences in salinity and temperature between sampling stations during each period, on Machu Picchu (MP) the lowest salinity and temperature were observed in December 2009, while at EACF the lowest values for both variables were registered in January 2010 (Figures 2a, b). Total chlorophyll biomass was on average higher in early summer $\left(0.34 \mu \mathrm{g} . \mathrm{L}^{-1}\right)$ than in late summer $\left(0.20 \mu \mathrm{g} . \mathrm{L}^{-1}\right)$, no significant differences were observed among sampling stations inside each sampling period (Figures 2c, d).

An average cellular density of $3 \times 10^{3} \pm 0.3 \times 10^{3}$ cells. $L^{-1}$ was observed for microplankton, with little variation between sampling periods $\left(\approx 10^{3}\right.$ cells. $\left.L^{-1}\right)$. The contribution is shared by the diatoms (mainly at the beginning of summer with 56\%) and dinoflagellates (at the end of the summer with 68\%). Among diatoms the pennate type was predominant (90\% in December 2009 and $70 \%$ in February 2010). Athecate forms, especially heterotrophs, were more abundant among dinoflagellates during February (69\%), while thecate forms representing 70\% of total dinoflagellates in December. Among sampling sites, microplankton registered maximum cellular density at MP due to the predominance of pennate diatoms during December 2009 (Figure 2e). 

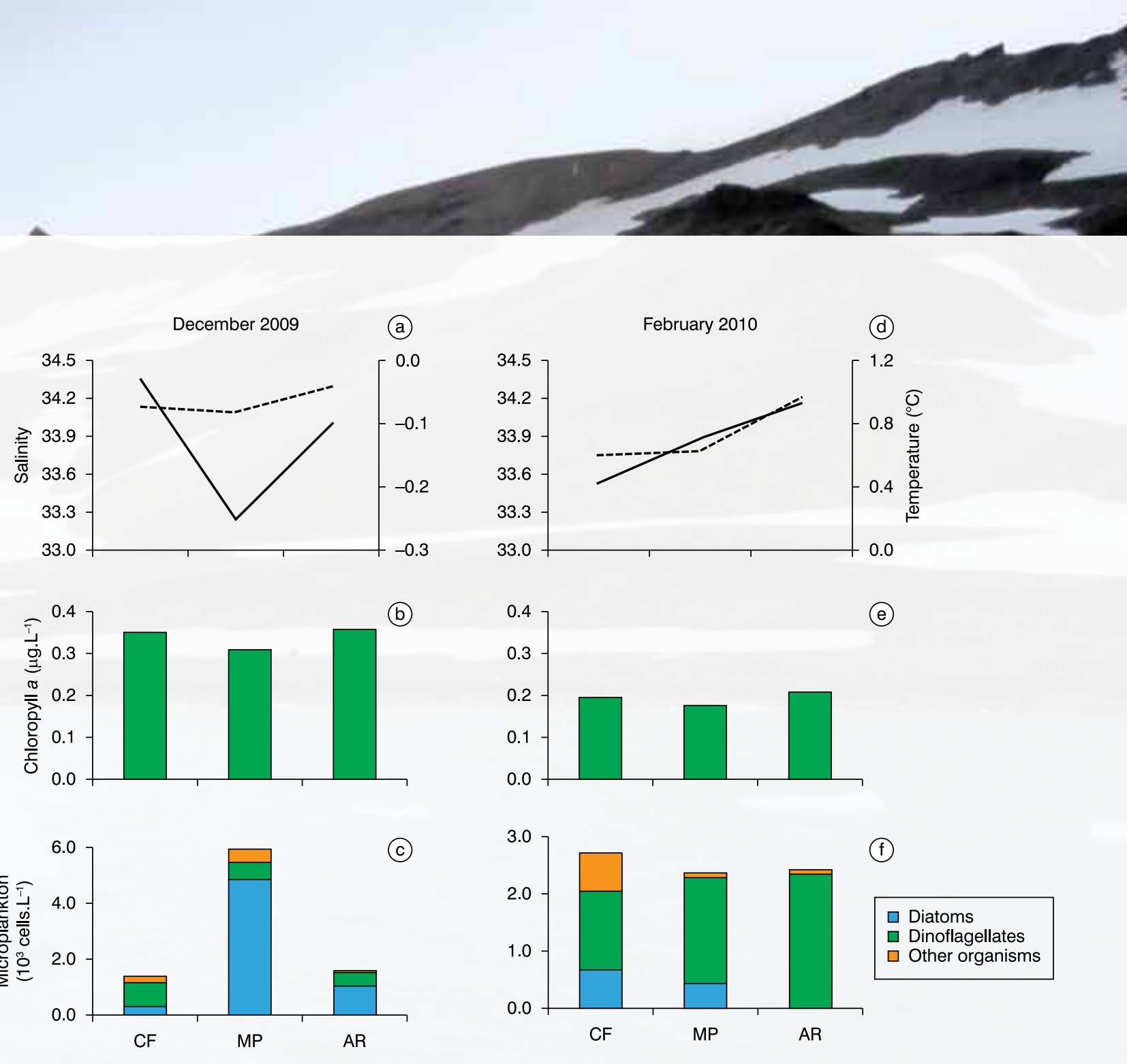

(f)

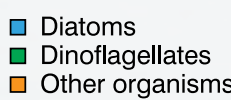

Sampling station

Figure 2. Results of salinity (continuous line), temperature (dotted line), chlorophyll a concentration ( $\mu \mathrm{g} . \mathrm{L}^{-1}$ ) and microplankton density (cells. $\mathrm{L}^{-1}$ ) at December 2009 (a, b and c) and February 2010 (d, e and f).

\section{Pico and Nanoplankton abundance and}

\section{size-fractioned chlorophyll in late summer}

During February 2009 pico- and nanoplankton densitiy did not show significant differences among sampling sites, but differences were observed among sampling periods $(p<0.01)$. Chla concentrations varying between 0.18 and $0.74 \mu \mathrm{g} . \mathrm{L}^{-1}$ were observed, with the size-fraction $<10 \mu \mathrm{m}$ representing more than $80 \%$ of the total. An increase in Chla concentrations was observed from the first to the last survey, although the fraction 2-10 $\mu \mathrm{m}$ registered higher values during the second survey (Figure $3 b$ ). Nanoplankton and picoplankton abundances showed a similar pattern, with higher mean values $\left(8.5 \pm 2.8 \times 10^{6}\right.$ and $1.2 \pm 0.2 \times 10^{11}$ cells. $\mathrm{L}^{-1}$, respectively) during the second survey (Figures $3 \mathrm{c}, \mathrm{d}$ ). The nanoplankton community was dominated by the autotrophic (>75\%) and 2-10 $\mu \mathrm{m}$ size-fraction, while the picoplankton was dominated by heterotrophs ( 99\%). Despite autotrophic cells represented only $<1 \%$ of picoplankton, abundances relatively high for this group were observed $\left(2.1-8.2 \times 10^{7}\right.$ cells. $\left.\mathrm{L}^{-1}\right)$. Autotrophic nanoplankton was positively correlated with total and $<10 \mu \mathrm{m}$ size-fraction of Chla $(p<0.01)$, although autotrophic picoplankton was negatively correlated with total and $<0.2 \mu \mathrm{m}$ size-fraction of Chla $(p<0.05)$.

\section{Discussion}

\section{Microplankton and total chlorophyll biomass between early and late summer}

Microplankton cellular densities and chlorophyll biomass observed in this study were low when compared to those registered for Admiralty Bay during the decades of the 
seasonal prevalence of cryptophytes (Moline et al., 2004). The dominance of pico and nano-size cells in phytoplankton, which are not grazed efficiently by Antarctic krill, will likely cause a shift in the spatial distribution of krill and may allow also for the rapid asexual proliferation of carbon poor gelatinous zooplankton, salps in particular (Moline et al., 2004), and probably the dominance of heterotrophic dinoflagellates observed during the late summer period of this study.

\section{Conclusion}

In the context of the regional warming trend of WAP, preliminary results of the present study showed a shift in Admiralty Bay plankton community, with significant variability both in short- and medium-term scales, from day to day and months. Low microplankton densities, dominance of dinoflagellates, mainly heterotrophs, and high contribution of autotrophs pico- and nanoplankton to total density and biomass in late summer, suggest that changes could be occurring in Admiralty Bay food web. Thus, it is necessary to continue the long-term monitoring program and the implementation of microvariation sampling effort to identify the factors that are actually influencing phytoplankton populations in this environment.

\section{Acknowledgements}

To the Instituto Nacional de Ciência e Tecnologia Antártico de Pesquisas Ambientais, contracts CNPq n 574018/2008-5 and FAPERJ n ${ }^{\circ}$ E-16/170.023/2008, Laboratório de Química Orgânica Marinha (LabQOM- USP), Instituto Oceanográfico (USP), Ministério do Meio Ambiente (MMA), Ministério de Ciência e Tecnologia (MCT) and Comissão Interministerial para os Recursos do Mar (CIRM). Also to Rafael Bendayan de Moura for Admiralty Bay map.

\section{References}

Brandini, F.P. (1993). Phytoplankton biomass in an Antarctic coastal environment during stable water conditions - implications for the iron limitation theory. Marine Ecology Progress Series, 93: 267-75.

Delille, D. (2004) Abundance and function of bacteria in the Southern Ocean. Cellular and Molecular Biology, 50(5): 543-51

Delille D.; Gleizon, F. \& Delille, B. (2007). Spatial and temporal variations of bacteria and phytoplankton in a subAntarctic coastal area (Kerguelen Archipelago). Journal of Marine Systems, 68(3-4): 366-80

Kopczynska, E.E. (1980). Small scale vertical distribution of phytoplankton in Ezcurra Inlet, Admiralty Bay, South Shetland Islands. Polish Polar Research, 1: 77-96

Kopczynska, E.E. (1981). Periodicity and composition of summer phytoplankton in Ezcurra Inlet, Admiralty Bay, King George Island, South Shetland Islands. Polish Polar Research, 2: 55-70.

Kopczynska, E.E. (2008). Phytoplankton variability in Admiralty Bay, King George Island, South Shetland Islands: six years of monitoring. Polish Polar Research, 29(2): 117-139.

Lange, P.K.; Tenenbaum, D.R.; Braga, E.S.B. \& Campos, L.S. (2007). Microphytoplankton assemblages in shallow waters at Admiralty Bay (King George Island, Antarctica) during the summer 2002-2003. Polar Biology, 30(11): 1483-92.

Lipski, M. (1987). Variations of physical conditions, nutrients and chlorophyll a contents in Admiralty Bay (King George Island, South Shetland Islands). Polish Polar Research, 8: 307-32.

Marshall G.J.; Lagun V. \& Lachlan-Cope T.A. (2002). Changes in Antarctic Peninsula tropospheric temperatures from 1956 to 1999: a synthesis of observations and reanalysis data. International Journal of Climatology, 22(3): 291-310.

Martinussen, I. \& Thingstad. T.F. (1991). A simple double-staining method for enumeration of autotrophic and heterotrophic nano- and picoplankton. Marine Microbial Food Webs, 5: 5-11.

Moline, M.A.; Claustre, H.; Frazer, T.K.; Schofield, O. \& Vernet, M. (2004). Alteration of the food web along the Antarctic Peninsula in response to a regional warming trend. Global Change Biology, 10: 1973-1980, doi: 10.1111/j.1365-2486.2004.00825.x 


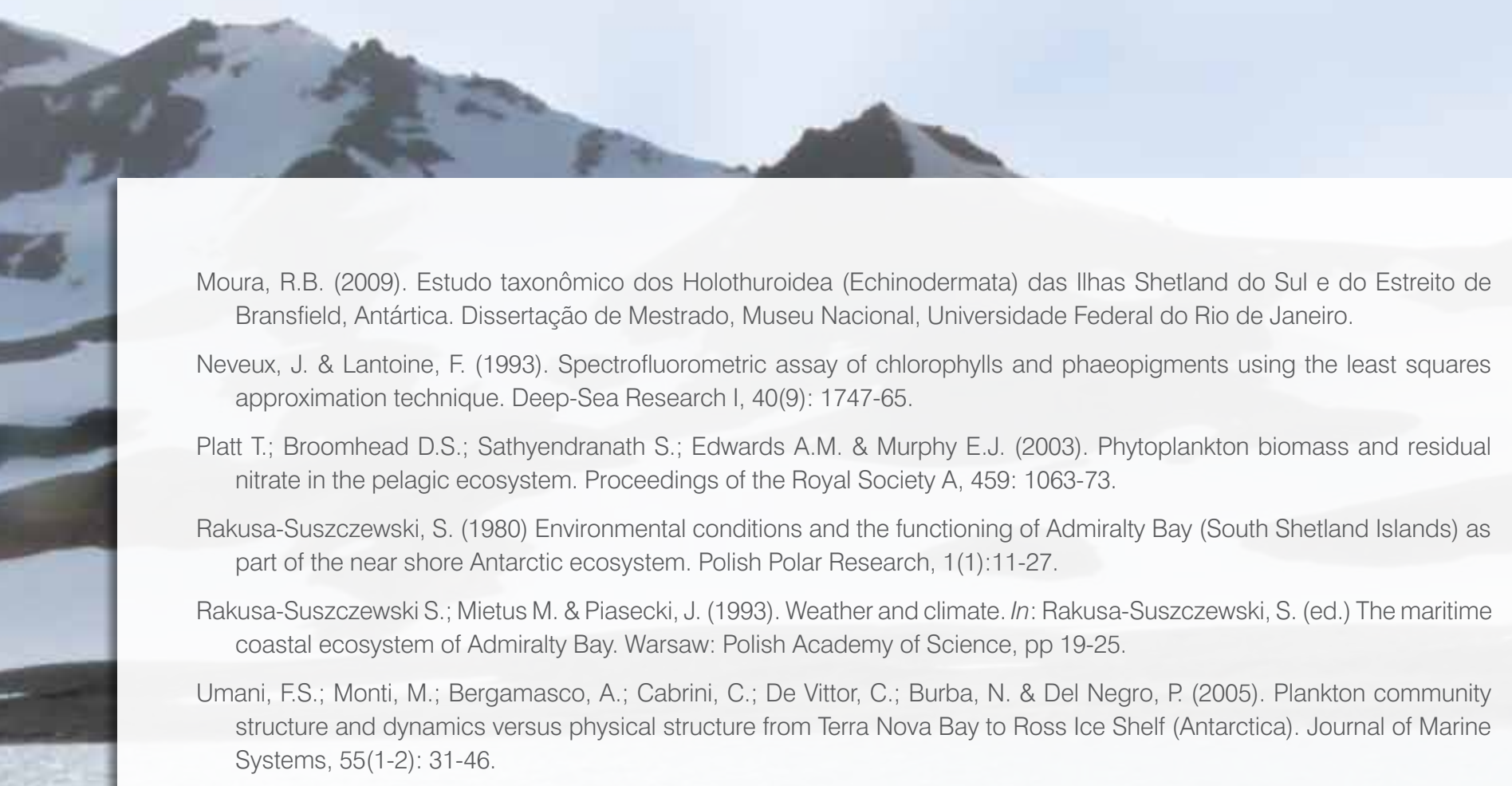

Utermöhl H. (1958). Zur Vervollkommung der quantitativen Phytoplankton-Methodik. Mitteilungen der Internationale Vereinigung für Teoretische und Angewandte Limnologie, 9: 1-38. 